\title{
Late detection of a shigellosis outbreak in a school in Madrid
}

J Jonsson ${ }^{1,5}$, M C del Álvarez-Castillo ${ }^{1,2}$, J C Sanz ${ }^{3}$, R Ramiro ${ }^{4}$, E Ballester ${ }^{1}$, M Fernánez ${ }^{3}$, A Echeíta ${ }^{4}$, J. F. Martinez Navarro ${ }^{1}$

Affiliations:

1 Programa de Epidemiología Aplicada de Campo, Centro Nacional de Epidemiología, Instituto de Salud Carlos III, Spain

2 Sección de Epidemiología del Servicio de Salud Pública del Área 7, Instituto de Salud Pública de la Comunidad de Madrid, Spain

3 Laboratorio Regional de Salud Pública, Instituto de Salud Pública de la Comunidad de Madrid, Spain

4 Laboratorio de Referencia de Salmonella y Shigella, Centro Nacional de Microbiología. Instituto de Salud Carlos III, Spain

5 European Programme for Intervention Epidemiology Training (EPIET)

Correspondence:

Citation style for this article: Jonsson J, del Álvarez-Castillo M C, Sanz J C, Ramiro R, Ballester E, Fernánez M, Echeíta A, Martinez Navarro J. F.. Late detection of a shigellosis outbreak in a school in Madrid. Euro Surveill. 2005;10(10):pii=571. https://doi.org/10.2807/esm.10.10.00571-en

Available Translations: English

Full-Text

J Jonsson ${ }^{1,5}$, M del Carmen Álvarez-Castillo ${ }^{1,2}$, JC Sanz ${ }^{3}$, R Ramiro ${ }^{4}$, E Ballester ${ }^{1}$, M Fernánez ${ }^{3}$, MA Echeita ${ }^{4}$, F Martínez Navarro ${ }^{1}$

1. Programa de Epidemiología Aplicada de Campo, Centro Nacional de Epidemiología, Instituto de Salud Carlos III, Spain

2. Sección de Epidemiología del Servicio de Salud Pública del Área 7, Instituto de Salud Pública de la Comunidad de Madrid, Spain

3. Laboratorio Regional de Salud Pública, Instituto de Salud Pública de la Comunidad de Madrid, Spain

4. Laboratorio de Referencia de Salmonella y Shigella, Centro Nacional de Microbiología. Instituto de Salud Carlos III, Spain

5. European Programme for Intervention Epidemiology Training (EPIET) 
Even though shigellosis in Spain is rare, an indigenous outbreak is occasionally detected. We describe an outbreak in a school in Madrid caused by person-toperson transmission of Shigella sonnei.

After the detection of Shigella sonnei in a stool sample from a 3 year old girl, an investigation at her school was initiated. Questionnaires were distributed to the parents of $\mathbf{5 2 0}$ pupils attending the school. A case was defined as a school case if it was the first case in a child's household, and as a household case if other members of the household had fallen ill first.

We identified 88 cases ( 60 pupils and 28 of their family members). The attack rate (AR) was $12 \%$ in the school and $32 \%$ in the families. There was a significant association between higher AR and lower age. The outbreak lasted for two months. The length and the shape of the epidemic curve of the 60 cases in pupils suggests person-to-person transmission. Shigella sonnei isolated from 5 different cases were typed by pulsed field gel electrophoresis (PFGE) and was found to be an identical strain. The prolonged duration of the outbreak was probably due to delayed detection, and stopped as soon as control measures were introduced. 


\section{Introduction}

On 31 May 2004, Shigella sonnei was isolated from a stool sample of a 3 yearold girl with gastroenteritis attending a school in Madrid. Our initial contact with the school identified 20 additional pupils with similar complaints during the month of May, most of them in children aged 3-5 years.

The school includes all levels from pre-school to secondary school, and also has a kindergarten. There are two classes in each year with 25 to 30 pupils in every class. The distribution was 148 pupils in preschool, 312 in primary school and 60 in the first year of secondary school.

Shigellosis in Spain has decreased markedly from about $1 \%-5 \%$ of all stool sample isolates in the 1980 s [1,2] to less than $1 \%$ in the late 1990 s $[3,4]$. Most of the cases reported are in travellers returning from developing countries [5]. Most sporadic non-imported waterborne $[6,8]$ or foodborne [9] outbreaks, and some outbreaks transmitted by person-to-person-spread [10] are detected.

Shigellosis is an invasive infection of the colon that is spread by the faecal-oral route. The low infective dose (10-100 bacteria) favours a high transmissibility. The incidence is high in developing countries and affects children more than adults [11]. In contrast to most other enteropathogens, the only reservoir of Shigella sp. is humans [12].

We conducted an investigation to confirm the existence of an outbreak and to identify the source and mode of transmission, in order to prevent the occurrence of more cases.

\section{Methods}

\section{Case finding}

To identify cases among pupils and their families, we distributed a questionnaire to the parents of all pupils in preschool (3-5 years), primary school (5-11 years) and first year of secondary school (11-12 years). The questionnaire collected information about the occurrence of gastroenteritis in their children since 15 April 2005.

Additionally, parents of pupils with gastroenteritis according to the questionnaires were interviewed by telephone to identify other cases among household members and collect their date of onset.

At our first visit at the school we contacted the parents and the physicians of pupils who were absent on that day due to gastroenteritis to make sure that stool samples were collected and antibiotic treatment considered.

\section{Case definition}

We defined a probable case as:

Any pupil at the school or anyone in their households who had acute onset of diarrhoea (>3 loose stools/day) after 15 April 2004 lasting for at least 3 days and at least two of the following symptoms:

- Blood and/or mucus in stool

- Fever $\left(>38^{\circ} \mathrm{C}\right)$ 
A confirmed case was a probable case with Shigella sonnei isolated from a stool sample. A case in a pupil was defined as a school case if it was the first case in the child's household. A household case was a case with date of onset after a school case had occurred in that household within the week before onset of symptoms.

\section{Epidemiological study}

We performed a descriptive analysis and calculated attack rates per educational level and in households.

Laboratory investigations

Stool cultures from some probable cases were performed according to standard methods [13]. Resistance to antibiotics was assessed using the minimal inhibitory concentration (MIC) of ampicillin, amoxicillin/clavulanic acid, cefotaxime, ceftazidime, nalidixic acid, ciprofloxacin, chloramphenicol, trimethoprim-sulfamethoxazole and tetracycline, determined by E-test (AB Biodisk, Izasa. Spain). For genotyping by pulsed field gel electrophoresis (PFGE) to identify the infective strain, the restriction enzyme Xbal (Roche, Spain) was used, following the agreed protocol from the Salm-gene project [14]. PFGE profiles were assigned to pulse types on the basis of one or more band differences between strains.

\section{Environmental investigations}

We visited the school to look at distribution and condition of toilets and canteens. No environmental samples were taken.

\section{Results}

The outbreak lasted two months [FIGURE]. Several clusters in time suggest waves compatible with person-to-person transmission.

When the first notification was received, 40 cases had already occurred in the school.

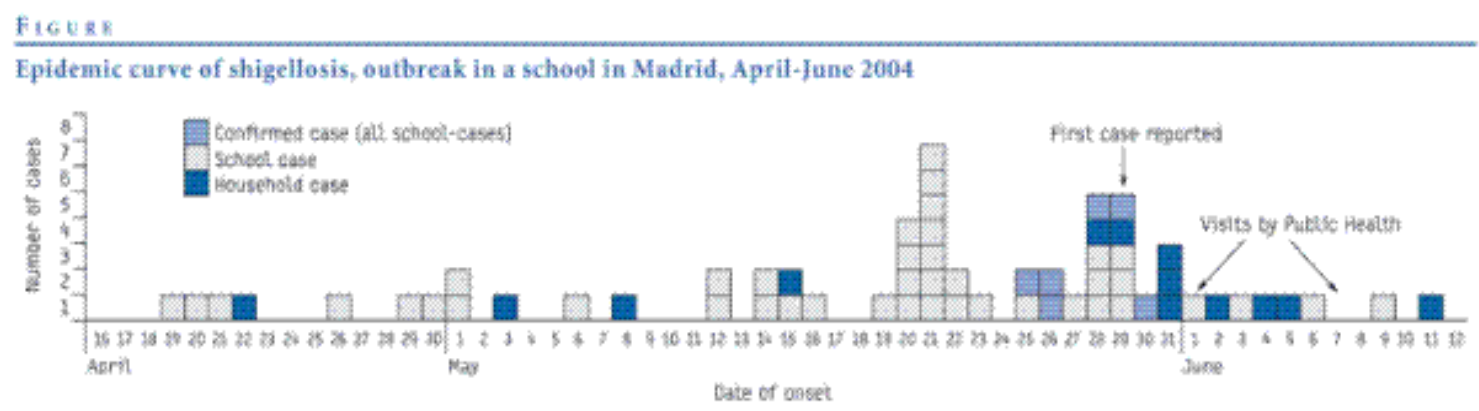

We distributed 520 individual questionnaires to parents of pupils at the school. Among the pupils 60 cases ( 54 probable and 6 confirmed) were identified (Attack Rate $(A R)=12 \%$, in 34 boys and 26 girls.

Of these 60 cases, 47 were defined as school cases and 13 as household cases [TABLE 1]. Of the 47 school cases, 25 caused between one and three more cases in a total of 130 household members exposed. Forty one of the 130 
exposed household members met the household case definition (including the 13 household cases among pupils), with an AR in households of $32 \%$ ). The mean incubation period was 5 days and the median 3 days (range $=0-7$ ). Of the 25 cases that caused secondary cases in their households, 24 were preschool pupils.

T A B L E 1

Distribution of school cases and household cases among pupils and their household contacts, outbreak in a school in Madrid, April-June 2004

\begin{tabular}{|l|c|c|c|} 
& School cases & Household cases & Total \\
\hline Pupils & 47 & 13 & 60 \\
\hline Household contacts & 0 & 28 & 28 \\
\hline Total & 47 & 41 & 88 \\
\hline
\end{tabular}

No cases were identified in teachers and there was no indication of spread to the community beyond the pupils' households.

The most frequent symptoms were diarrhoea (100\%), fever $>38^{\circ} \mathrm{C}(98 \%)$, abdominal pain (92\%), nausea or vomiting (62\%) and blood or mucus in stool (51\%). The duration of symptoms ranged from 3 to 14 days with a mean of 7 days. One pupil was admitted to hospital.

The AR was higher in lower educational level [TABLE 2]. Only one case occurred in a secondary school pupil. Using this as a reference, the risk ratio (RR) in primary school level was $2.8(95 \% \mathrm{Cl}$ : $0.4-21.4)$ and in preschool 17.5 (95\% Cl: 2.5-126.6).

\section{T A B LE 2}

Incidence and risk ratio (RR) of shigellosis according to educational level, outbreak in a school in Madrid, April-June 2004

\begin{tabular}{|l|c|c|c|c|c|}
\hline $\begin{array}{l}\text { Educational } \\
\text { level }\end{array}$ & $\begin{array}{c}\text { No. of } \\
\text { pupils }\end{array}$ & $\begin{array}{c}\text { No. of } \\
\text { cases }\end{array}$ & $\begin{array}{c}\text { Incidence } \\
(\%)\end{array}$ & RR & $95 \%$ CI \\
\hline $\begin{array}{l}\text { Secondary } \\
\text { school }\end{array}$ & 60 & 1 & 1.7 & Ref. & \\
\hline $\begin{array}{l}\text { Primary } \\
\text { school }\end{array}$ & 312 & 15 & 4.8 & 2.8 & $0.4-21.4$ \\
\hline Preschool & 148 & 44 & 29.7 & 17.5 & $2.5-126.6$ \\
\hline Total & $\mathbf{5 2 0}$ & $\mathbf{6 0}$ & $\mathbf{1 1 . 5}$ & & \\
\hline
\end{tabular}

Eight faecal samples were taken for culture from the 60 cases in pupils, and Shigella sonnei was isolated from six of these. Five of the isolates were phenotyped and genotyped. They all corresponded to phase I of Shigella sonnei serotype D and had identical profiles of susceptibility. The typing by PFGE of these five strains confirmed that they were identical and different from other 
strains analysed at the same time.

When visiting the school we found that preschool pupils (3-5 years) had separate toilets from the older pupils, and were not always accompanied to the toilet by members of staff. The toilets had textile towels for shared use. We recommended ensuring that the youngest pupils were always accompanied to the toilets by members of staff, replacing the textile towels with disposable paper towels, and emphasising to the children the importance of proper hand washing after using the toilets. We also recommended making sure that any pupil with diarrhoea remained at home until the symptoms had resolved completely. There was a follow-up visit one week later to ensure that the recommended measures had been implemented.

After the second visit to the school, only two further cases occurred in pupils. The last case was defined as a household case. The school closed for the summer holidays on 22 June, and no further cases were registered during the last 11 days of term.

\section{Discussion}

This outbreak of shigellosis had been occurring for more than a month before it was detected but ceased as soon as control measures were installed.

The suspicion of a common source was discarded since the epidemiological curve suggests person-to-person transmission. It is possible that cases with mild symptoms, excluded by the case definition, still contributed to spread. Shigellosis usually shows a higher attack rate in children than in adults [8] and children under 4 years of age are most susceptible [10]. Outbreaks in school settings, mainly in preschool age groups, are relatively frequent $[10,15]$ with an attack rate of secondary cases in their household contacts that may reach $40 \%$ $[16,17]$.

The household attack rate is in concordance with other studies $[15,16]$ and confirms a person-to-person transmission even outside the school setting. The distribution of the school cases according to educational level suggests different exposures at different levels. We did not consider an observational study of children's behaviour in the toilets necessary to deduce that it was likely to be related to the less well-developed hygiene habits of younger pupils who had their own toilets not shared with the older pupils. Of the 25 cases causing secondary cases in the pupils' households, all but one were in preschool pupils, which supports our theory of age and hygiene.

The isolates of Shigella sonnei from five different patients had similar patterns of antibiotic susceptibility. The molecular typing results confirmed that they were identical. Cases' symptoms were relatively severe compared with previous outbreaks of shigellosis in Spain [6], with $50 \%$ of the cases having dysentery and a high percentage having fever, abdominal pain and vomiting. 
taken, hence the absence of specific treatment and delayed installation of control measures that contributed to the dissemination of the infection [18]. In contrast with gastroenteritis caused by other bacteria, antibiotics are usually indicated in shigellosis, to reduce contagiousness.

In Spain, shigella infection is notifiable by laboratories. If paediatric physicians can be encouraged to take more samples, outbreaks could be detected more rapidly.

Controlling outbreaks of shigellosis requires timely reporting so that close contacts of a case can be informed of the need for strengthened hygiene, and when outbreaks occur in a school setting, it is important that ill children stay at home until their diarrhoea has ceased completely [15]. 


\section{References}

1. Velasco AC, Mateos ML, Mas G, Pedraza A, Diez M, Gutiérrez A. Three-year prospective study of intestinal pathogens in Madrid, Spain. J Clin Microbiol. 1984; 20 (2): 290-292.

2. Castillo FJ, Carranza E, Clavel A, Rubio MC, Gómez-Lus R. Epidemiología de la shigelosis y colicinotipia de Shigella sonnei. Un estudio de 14 años. Enferm Infecc Microbiol Clin. 1991;9(9): 530-536.

3. Prats G, Llovet T, Muñoz C, Sole R, Mirelis B, Izquierdo C, et al. Etiología de las enteritis en un hospital general universitario en Barcelona (1992-1995). Enferm Infecc Microbiol Clin. 1997;15 (7): 349-356.

4. Prats G, Mirelis B, Llovet T, Muñoz C, Miro E, Navarro F. Antibiotic resistance trends in enteropathogenic bacteria isolated in 1985-1987 and 1995-1998 in Barcelona. Antimicrob Agents Chemother. 2000 May;44(5):1140-5.

5. Navia MM, Ruiz J, Vila J. Molecular characterization of the integrons in Shigella strains isolated from patients with traveler's diarrhoea. Diagn Microbiol Infect Dis. 2004 Mar;48(3):175-9.

6. López-Hernández B, Jiménez de la Higuera A, Maeso-Villafana J. Estudio de un brote de gastroenteritis de transmisión hídrica. Aten Primaria.

1996;17(3):234-235.

7. Jiménez M, Fuster C, Raya C, Díaz A, Carbajal J. Brote de disenteria por Shigella boydii en la comarca de El Bierzo. Enferm Infecc Microbiol Clin. 1996;14(3):155-159.

8. Morera MA, Espejo E, Coll P, Simo M, Uriz MS, Llovet T, et al. Brote epidémico de shigelosis por ingesta de agua. Enferm Infecc Microbiol Clin. 1995;13(3): 160-165.

9. García-Fulgueiras A, Sánchez S, Guillén JJ, Marsilla B, Aladueña A, Navarro C. A large outbreak of Shigella sonnei gastroenteritis associated with consumption of fresh pasteurised milk cheese. Eur J Epidemiol. 2001;17(6):533-8.

10. Chover-Lara JL, Salazar-Cifre A, Gallego-Cruz M, Camaro-Sala ML, SegarraMartínez C, Peñalver-Blasco MC. Brote de shigellosis en un barrio de nivel social. Rev Esp Salud Publica. 1999; 73(3):393-401.

11. Sansonetti PJ. Microbes and microbial toxins: paradigms for microbialmucosal interactions III. Shigellosis: from symptoms to molecular pathogenesis. Am J Physiol Gastrointest Liver Physiol. 2001 Mar;280(3):G319-23 12. Wachsmuth K, Morris GK1989. Shigella. In: Doyle, M.P. (ed) Foodborne Bacterial Pathogens. Marcel Dekker Inc. pp. 447-462.

13. Bopp CA, Brenner FW, Fields PI, Wells JG, Strockbine NA. Escherichia, Shigella and Salmonella. In: Murray PR, Baron EJ, Jorgensen JH, Pfaller MA and Yolken RH (ed.) 2003. Manual of clinical microbiology, 8th edition, Washington DC: ASM; 2003. 42: 654-671.

14. Peters TM, Maguire C, Threlfall EJ, Fisher IST, Gill N, Gatto AJ. The Salmgene project - a European collaboration for DNA fingerprinting for food-related salmonellosis. Euro Surveill. 2003 Feb;8(2):46-50.

15. Suspiro A, Menezes L. An outbreak of shigellosis in a child care institution in 
Queluz, Portugal - 1995. Euro Surveill. 1996 Jan;1(1):4.

16. Chin J. Shigelosis. In: El control de las enfermedades transmisibles.

Organización Panamericana de la Salud. Publicación Científica y Técnica n 581 , $17^{a}$ edición. Washington DC, 2001. pp. 566-571.

17. Centers for Disease Control and Prevention (CDC). Day care-related outbreaks of rhamnose-negative Shigella sonnei-six states, June 2001-March 2003. MMWR Morb Mortal Wkly Rep. 2004 Jan 30;53(3):60-3.

18. Tauxe RV, Johnson KE, Boase JC, Helgerson SD, Blake PA. Control of day care shigellosis: a trial of convalescent day care in isolation. Am J Public Health. 1986 Jun;76(6):627-30.

Comment has been disabled for this content 